\title{
CONTAGION EFFECT ANTAR NEGARA ASEAN-5
}

\author{
R. Adisetiawan, Ahmadi \\ Dosen Fakultas Ekonomi Universitas Batanghari
}

\section{ABSTRACT}

This study was conducted to determine whether there is a contagion effect on the stock exchanges among ASEAN-5 countries (Indonesia, Singapore, Malaysia, Thailand and Philippines) during 2001.1 - 2018.5 period using the monthly return data of the five ASEAN-5 stock exchanges. This study uses granger causality test to see the direction of mutual influence that indicates the existence of contagion effect. The results revealed that the Indonesian stock exchange has a mutually influential relationship with the Thai stock exchange.

Keywords: contagion effect, return, granger causality test

\section{PENDAHULUAN}

Pengertian pasar modal menurut Undang-undang Pasar Modal No. 8 Tahun 1995 adalah Pasar Modal yaitu sebagai suatu kegiatan yang bersangkutan dengan penawaran umum dan perdagangan efek, perusahaan publik yang berkaitan dengan efek yang diterbitkannya, serta lembaga dan profesi yang berkaitan dengan efek. Pasar modal memiliki peranan penting bagi perekonomian suatu negara dan merupakan sebuah alternatif sektor keuangan selain perbankan. Pasar modal juga merupakan sarana yang digunakan para investor baik perusahaan maupun individu dalam mencapai tujuan utama dari berinvestasi yaitu memperoleh keuntungan. Sebelum melakukan investasi- investor perlu memastikan bahwa investasi yang akan dilakukan dapat memberikan tingkat pengembalian yang diharapkan. Tingkat pengembalian memiliki hubungan yang erat dengan risiko yang dihadapi saat melakukan investasi. Risiko yang dihadapi investor terbagi atas dua yaitu risiko sistematik dan risiko non-sistematik (unique risk). Risiko yang tidak dapat dihindari adalah risiko sistematik yang merupakan risiko yang terjadi secara makro seperti risiko inflasi, nilai tukar mata uang, dan tingkat suku bunga. (Adisetiawan, 2017).

Selama beberapa tahun belakangan terjadi krisis besar yang merupakan risiko sistematik dan sangat mempengaruhi ekonomi dunia yaitu krisis keuangan global yang terjadi di Amerika Serikat Serikat (2008) dan krisis hutang yang terjadi di benua Eropa (2010). Krisis Amerika Serikat Serikat pada tahun 2008, berawal dari permasalahan kegagalan pembayaran kredit perumahan (subprime mortgage default) di Amerika Serikat Serikat (AS). Krisis kemudian menggelembung merusak sistem perbankan bukan hanya di AS, namun meluas hingga ke Eropa lalu ke Asia, secara beruntun menyebabkan efek domino terhadap solvabilitas dan likuiditas lembaga-lembaga keuangan di negara-negara tersebut, yang antara lain menyebabkan kebangkrutan ratusan bank, perusahaan sekuritas, reksadana, dana pensiun dan asuransi. Krisis merambat ke belahan Asia terutama negara-negara seperti Jepang, Korea, China, Singapura, Hongkong, Malaysia, Thailand termasuk Indonesia yang kebetulan sudah lama memiliki surat-surat berharga lembaga-lembaga keuangan tersebut. (Adisetiawan, 2017).

Krisis Amerika Serikat yang terjadi pada tahun 2008 memberikan dampak negatif bagi bursa saham dibeberapa negara. Pada penutupan perdagangan saham akhir pekan Jumat (24/10/2008) IHSG turun sebesar 92,390 poin $(6,91 \%)$ menjadi $1.244,864$; posisi terendah sejak Juni 2006 . IHSG mengikuti pelemahan bursa saham Asia yang semakin memburuk seperti Hang Seng turun 8,3\%; KOSPI turun 10,33\%; Nikkei turun 9,6\%; Shanghai turun 1,92\%; STI Singapura turun 8,73\% dan Taiwan turun 3,19\% (www.finance.detik.com, 2008:3). Pengaruh krisis Subprime mortgage menurut BI (Bank Indonesia) melalui PEKKI (Perkembangan Ekonomi Keuangan dan Kerjasama International) dirasakan oleh kelima negara ASEAN-5 dimana negara Singapura menjadi negara pertama yang mengalami kontraksi ekonomi diantara negara ASEAN-5 pada triwulan ke tiga tahun 2008 bersama dengan negara Jepang, Selandia Baru dan Taiwan. Ekonomi negara Malaysia, Thailand dan Filipina juga mengalami kontraksi pada triwulan pertama tahun 2009. Negara Filipina memiliki tingkat penganguran yang tinggi yaitu sebesar 7,7\% akibat krisis yang terjadi. Indonesia terkena dampak dari krisis terutama nilai ekspor ke negara Eropa dan AS yang menurun tajam sehingga membuat 
pertumbuhan ekonomi Indonesia menjadi melambat (Yoshendy, 2012). Oleh karena adanya kesamaan terkena dampak negatif dari krisis subprime mortgage 2008, ASEAN-5 digunakan sebagai objek penelitian.

Tahun 2010, krisis terjadi pada negara-negara Uni Eropa. Krisis hutang benua Eropa yang merupakan Krisis ekonomi yang berawal dari negara Yunani dan menimbulkan efek domino. Berturut-turut ekonomi Irlandia, Portugal, Italia, dan Spanyol terguncang. Dampak krisis ini juga mulai terasa di Indonesia melalui jalur keuangan dan jalur perdagangan. Jalur keuangan terlihat dari anjloknya Indeks Harga Saham Gabungan (IHSG). Jalur perdagangan terlihat melalui penurunan ekspor (www.infografis.kompas.com, 2012).

Krisis juga pernah terjadi pada pertengahan tahun 1997, dimana hampir semua negara-negara ASEAN mengalami krisis ekonomi. Dimulai dari negara Thailand yang mengalami kesulitan akibat semakin membesarnya defisit transaksi berjalan negara tersebut selama lebih kurang lima tahun terakhir. Keadaan ini diperberat oleh memburuknya kinerja perbankan Thailand yang diakibatkan oleh besarnya kredit macet yang belum teratasi. Masalah yang terjadi menimbulkan krisis ekonomi yang ditandai dengan jatuhnya nilai tukar mata uang Baht terhadap dolar Amerika Serikat, besarnya arus modal keluar negeri (capital outflows), dan menipisnya cadangan devisa untuk pembangunan. Kemudian krisis ini menjalar ke negara ASEAN lain seperti Fhilipina, Malaysia, Singapura, dan Indonesia. Jatuhnya nilai tukar mata uang tentu saja memberikan pengaruh negatif bagi pasar modal yang terkena dampak krisis. Good market approach (Dornbusch \& Fischer, 1980) menyatakan perubahan mata uang atau kurs mempengaruhi competitiveness suatu perusahaan, yang selanjutnya mempengaruhi pendapatan perusahaan atau cost of fund dan kemudian mempengaruhi harga sahamnya. Krisis yang terjadi memberikan dampak negatif bagi pasar modal negaranegara ASEAN.

Fakta-fakta yang telah dijabarkan dapat dilihat bahwa setiap krisis yang terjadi di suatu negara akan memiliki dampak negatif bagi negara lain. Hal tersebut mengindikasikan bahwa negara-negara tersebut memiliki integrasi pada bidang ekonomi dan memberikan dugaan adanya hubungan mempengaruhi dan dipengaruhi atau yang lebih dikenal dengan contagion effect. Contagion effect atau efek menular adalah suatu fenomena ketika krisis keuangan yang terjadi pada suatu negara akan memicu krisis keuangan atau ekonomi pada negara lain (Trihadmini, 2011). Contagion effect menular/ terjadi jika terdapat hubungan dagang (trade links) dan kesamaan kondisi dan kebijakan makroekonomi (Harjito, 2010). Efek penularan (contagion effect) dapat terjadi bagi semua kejadian diberbagai bidang, baik krisis ekonomi maupun keuangan. Krisis di bidang keuangan seperti fluktuasi harga saham yang terjadi di suatu pasar modal berdampak pada fluktuasi menurunnya return saham dan pada akhirnya berpengaruh pada pola abnormal return sebagai tolok ukur kinerja saham yang bersangkutan, karena adanya indikasi terdapatnya contagion effect pada saat terjadinya krisis, maka akan dilakukan pengujian apakah ada hubungan saling mempengaruhi dan dipengaruhi pada saat terjadi krisis di Amerika Serikat di antara negara ASEAN-5 dengan menggunakan Granger Causality test. Granger Causality test digunakan untuk bisa mengetahui arah kausalitas yang terjadi antar negara ASEAN-5 pada saat terjadi krisis pada tahun 2008 dengan periode pengamatan yang digunakan adalah 2001.1 - 2018.5. Periode ini ditentukan berdasarkan analisa PDB (Produk Domestik Bruto) negara Amerika Serikat dimana PDB diyakini sebagai indikator ekonomi terbaik dalam menilai perkembangan ekonomi suatu negara (Bank Indonesia, 2012).

Krisis Amerika Serikat sendiri dipilih karena merupakan krisis global yang sangat luas dampak krisisnya. Selain itu, Amerika Serikat sendiri merupakan negara adidaya yang tidak diprediksi bisa mengalami krisis dan negara ASEAN-5 merupakan negara kumpulan yang terbentuk sejak tahun 1967, terkena dampak krisis tahun 1997 dan 2008, memiliki kerjasama sejak awal terbentuk di bidang ekonomi, memiliki letak geografis yang saling berdekatan, dan mempunyai pasar modal yang memiliki karakteristik yang serupa yaitu masih kurangnya penyebaran informasi dan transparansi (Harjito, 2010).

\section{Landasan Teori}

\section{Peran dan Manfaat Pasar Modal}

Secara umum peran dan manfaat yang diperoleh dari pasar modal menurut Otoritas Jasa Keuangan (2016) adalah :

a. Pasar modal merupakan wahana pengalokasian dana secara efisien. 
Investor dapat melakukan investasi pada beberapa perusahaan melalui pembelian efek-efek yang baru ditawarkan ataupun yang diperdagangkan di pasar modal. Sebaliknya, perusahaan dapat memperoleh dana yang dibutuhkan dengan menawarkan instrumen keuangan jangka panjang melalui pasar modal tersebut.

b. Pasar modal sebagai alternatif investasi pasar modal memudahkan alternatif berinvestasi dengan memberikan keuntungan dengan sejumlah risiko tertentu

c. Memungkinkan para investor untuk memiliki perusahaan yang sehat dan berprospek baik. Perusahaan yang sehat dan mempunyai prospek yang baik, sebaiknya tidak hanya dimiliki oleh sejumlah orangorang tertentu saja, karena penyebaran kepemilikan secara luas akan mendorong perkembangan perusahaan menjadi lebih transparan.

\section{Contagion Effect Theory}

Bank Dunia mempunyai tiga definisi tentang contagion effect (Yang, 2002). Pertama, contagion dalam arti luas adalah kejutan yang ditransmisikan melewati lintas batas negara, atau terjadinya hubungan saling mempengaruhi antar beberapa negara. Contagion dapat terjadi dalam kondisi normal ataupun krisis. Kedua, transmisi dari suatu kejutan melewati lintas batas negara atau secara umum terjadinya korelasi yang signifikan antar negara yang terjadi diluar beberapa saluran fundamental. Ketiga, menghubungkan contagion dengan suatu fenomena ketika korelasi antar negara meningkat selama periode krisis dibandingkan dengan korelasi pada periode perekonomian normal.

Berkaitan dengan contagion terdapat dua penafsiran utama, yang pertama berasal dari interpendensi adanya saling ketergantungan antar ekonomi pasar seperti kesamaan makro ekonomi, hubungan dagang dan pinjaman dari bank (kredit bank) (Barry, Rose \& Wyploz, 1996). Rijckeghm dan Weder (1999) serta Kim dan Sheen (2001) menyatakan bahwa kredit bank serta perilaku investor melalui saluran finansial merupakan sumber penting yang memicu krisis, hipotesis tentang kreditor yang sama dilandaskan pada kecenderungan lembaga peminjam untuk membatasi pinjaman ketika bank mengalami kerugian. Ketika lembaga-lembaga finansial mengalami default di suatu negara, mereka cenderung untuk menarik modal bukan hanya di negara itu saja, melainkan juga dari negara-negara lainnya, agar mereka bisa menghindari penurunan lebih jauh nilai aset mereka. Kategori contagion kedua menekankan pada perilaku investor. Jenis contagion ini berasal dari asimetri information, perilaku secara kolektif dan hilangnya kepercayaan tanpa memandang kinerja makro ekonomi suatu negara yang bersangkutan. Hal ini terjadi karena para pelaku pasar modal sebenarnya banyak menerima informasi yang sama (melalui alat komunikasi yang sama, seperti Reuters), sehingga suatu reaksi atas sepotong informasi yang baru dapat menyebar ke seluruh dunia dalam waktu yang singkat dan menyampaikan pesan pada pelaku pasar modal internasional untuk melakukan reaksi yang sama. Presepsi pasar ini, bisa ditafsirkan oleh para investor di pasar lainnya sebagai suatu indikasi akan munculnya suatu krisis dalam waktu dekat (Barry, Rose \& Wyplosz, 1996).

Krisis negara-negara Asia tahun 1997 menurut penelitian Bank Dunia terutama disebabkan oleh adanya contagion effect (domino effect) dari negara lain (Tan, Jose Antonio, 1998). Menurut riset yang dilakukan oleh Eun dan Shim (1989) pasar Amerika Serikat adalah pasar modal yang paling berpengaruh, sehingga perubahan pasar Amerika Serikat akan dapat mempengaruhi pergerakan pasar modal lainnya. Krugman (1999), menyatakan bahwa dua hal penting tentang pemikiran para ekonom mengenai krisis mata uang dan saham. Pertama, menganalisis dasar-dasar perekonomian secara terpisah tidak memungkinkan kita untuk bisa memahami penyebab dan dinamika dari krisis keuangan dan saham, dan yang kedua, adalah bahwa krisis cenderung untuk menjalar padahal kurang sekali pengetahuan yang kita miliki untuk memahami secara pasti mengapa krisis bisa menjalar ke negara-negara lainnya.

\section{Kajian Penelitian Terdahulu}

Penelitian sebelumnya yang menjadi rujukan dalam penelitian ini adalah:

a. Penelitian yang dilakukan Monica Weni Pratiwi yang berjudul pendekatan Contagion Theory Terhadap Krisis Dubai mencoba mengkaji pengaruh krisis Dubai terhadap return saham di negara Indonesia, Malaysia, Singapura, Thailand, dan Philipina (Contagion Theory). Data yang digunakan dalam penelitian ini adalah nilai harga saham dua bulan sebelum dan dua bulan sesudah pemerintah Dubai menyatakan 
default, yaitu pada tanggal 28 November 2009. Metode yang digunakan adalah meregresikan negara origin dengan negara afektif. Berdasarkan analisis yang dilakukan, diketahui harga saham Dubai berpengaruh terhadap harga saham Malaysia pada hari ketiga dengan tingkat signifikansi $10 \%$. Harga saham Malysia berpengaruh terhadap harga saham Singapura pada hari ketiga dengan tingkat signifikansi $1 \%$. Selain itu, harga saham Malaysia berpengaruh terhadap harga saham Thailand pada hari pertama dengan tingkat signifikansi $10 \%$.

b. Penelitian yang dilakukan Hsien-Yi Lee yang berjudul Contagion in International stock Markets during the Sub Prime Mortgage Crisis yang menggunakan dua puluh indeks saham internasional, penelitian ini menguji apakah contagion effect terjadi di pasar internasional sebelum dan setelah krisis subprime mortgage keuangan di AS dengan menggunakan data harian indeks saham AS periode 23 Juli 2006 sampai dengan 22 Juli 2007 dan 23 Juli 2007 sampai dengan 22 Januari 2008. Menggunakan heteroscedaticity biases didasarkan pada koefisien korelasi untuk menguji adanya contagion effect, penelitian ini menunjukkan bahwa pasar saham dari beberapa negara (yaitu Hong Kong, Taiwan,Australia dan Selandia Baru) tidak terkena dampak contagion effect.

c. Penelitian yang dilakukan Neeltje van Horen, Henk Jager, dan Frac Klaassen yang berjudul Foreign Exchange Market Contagion in the Asian Crisis: A Regression-Based Approach penelitian ini mengkaji apakah, selama krisis Asia, terjadi contagion dari Thailand ke negara krisis lain melalui pasar uang dan, menentukan kontribusi penularan ini terhadap krisis. Lebih khusus dari penelitian ini diuji apakah efek dari tekanan pasar uang Thailand, negara asal krisis, pada pasar uang dari empat negara krisis Asia meningkat selama krisis. Menggunakan data EMP (exchange Market Pressure) yaitu nilai tukar dan tingkat suku bunga periode January 1995 sampai dengan Juli 1998. Untuk mengukur contagion yang terjadi digunakan koefisien korelasi, dan kemudian diterapkan analisis regresi. Dari penelitian ini ditemukan bukti penularan dari Thailand ke Indonesia dan Malaysia, dengan 13\% dan 21\% dari tekanan pada mata uang masing diatribusikan contagion. Untuk Korea dan Filipina tidak ada bukti contagion dari Thailand.

d. Penelitian yang dilakukan Ludovicius Sensi Wondabio yang berjudul Analisa Hubungan Index Harga Saham Gabungan (IHSG) Jakarta (JSX), London (FTSE), Tokyo (NIKKEI), dan Singapura (SSI). Tujuan dari penelitian ini adalah untuk menganalisis hubungan antara Indeks Harga Saham Jakarta (BEJ) dan London Stock Price Index (FTSE), Tokyo Stock Price Index (NIKKEI) dan Singapore Stock Price Index (SSI) menggunakan model ekonometrik dari heterokedastisitas Autokorelasi Kondisi $(\mathrm{ARCH}) /$ Autokorelasi heterokedastisitas Kondisi Generalized $(\mathrm{GARCH})$ dan autoregresi Vector (VAR) untuk periode 2001-2005. Berdasarkan hasil penelitian ini, pola hubungan antara BEJ dan FTSE, NIKKEI dan SSI memiliki pola perbedaan dan karakteristik yang unik. FTSE dan NIKKEI memiliki dampak yang signifikan terhadap BEJ BEJ tetapi tidak memiliki dampak terhadap FTSE dan NIKKEI. Kondisi ini telah menyetujui bahwa negara-negara maju memiliki dampak yang signifikan terhadap perekonomian negara berkembang. Hubungan antara BEJ dan SSI memiliki dampak negatif terhadap BEJ.

e. Penelitian Adisetiawan (2017) mengungkapkan bahwa selama periode 2001-2016 dan pada tingkat keyakinan 99\% terjadi kausalitas antara indeks pasar modal Taiwan (TWSE) dengan indeks pasar modal Indonesia (IHSG), dan hubungan kointegrasi jangka panjang dan pengaruh yang sangat signifikan antara indeks pasar modal Indonesia (IHSG) dengan indeks pasar 11 negara (Singapore, Malaysia, Thailand, Philippina, Korea Selatan, Hongkong, Jepang, Taiwan, Amerika, Inggris, dan Australia). Hasil penelitian juga membuktikan bahwa pasar modal Indonesia telah terintegrasi dengan pasar modal global dengan derajat yang bervariasi antar jenis pasar modal global, hal ini ditunjukkan oleh pergerakan yang searah dan pengaruh perkembangan pasar modal global yang signifikan di pasar modal Indonesia. Meskipun terintegrasi, masing-masing pasar modal global memiliki tingkat integrasi yang bervariasi.

\section{Hipotesis}

Untuk mendapatkan hasil empirik dari penelitian ini, hipotesa yang ada perlu ditetapkan dan diuji. Hipotesa penelitian ini disusun berdasarkan rumusan masalah yang ada, sehingga dapat ditarik hipotesa dalam penelitian ini, yaitu: return indeks masing-masing negara ASEAN (Indonesia, Singapura, Malaysia, Thailand, dan Filipina) saling mempengaruhi secara signifikan. 


\section{METODE}

Populasi merupakan jumlah keseluruhan obyek yang akan diteliti. Dalam penelitian ini populasi yang digunakan adalah data harian Indeks komposit lima negara: Indonesia (IHSG), Singapura (STI), Malaysia (KLSE), Thailand (SET50), Filipina (PSEI) yang mewakili saham yang terdaftar pada bursa saham masing-masing negara. Sampel yang digunakan dalam penelitian ini adalah data closing price bulanan Indeks komposit lima negara: Indonesia (IHSG), Singapura (STI), Malaysia (KLSE), Thailand (SET50), Filipina (PSEI) periode 2001.1-2018.5. Jenis data yang digunakan adalah data sekunder, yaitu data yang diperoleh secara tidak langsung melalui media perantara atau biasanya telah dikumpulkan oleh lembaga pengumpul data. Data sekunder yang diperlukan dalam penelitian ini diperoleh dari website yahoo finance, dan website resmi Thailand Stock Exchange (www.SET.or.th).

Metode pengumpulan data dalam penelitian ini adalah penelitian dokumenter. Pengumpulan data dilakukan dengan kategorisasi dan klasifikasi bahan-bahan tertulis yang terkait dengan penelitian, lalu melakukan studi kepustakaan dengan mempelajari buku-buku dan literatur, jurnal-jurnal ekonomi, dan bacaan lain yang berhubungan dengan pasar modal. Dalam penelitian ini, pengumpulan dilakukan dengan melakukan pencatatan harga penutupan bulanan Indeks komposit lima negara: Indonesia (IHSG), Singapura (STI), Malaysia (KLSE), Thailand (SET50), Filipina (PSEI) yang mewakili saham yang terdaftar pada bursa saham masing-masing negara periode 2001.1-2018.5.

\section{Teknik Analisa Data}

Langkah pertama setelah data didapatkan adalah menyamakan jumlah hari kerja antara satu negara dengan negara yang lain dengan asumsi semua negara yang dipilih sebagai negara yang akan diteliti (Indonesia, Singapura, Malaysia, Thailand, Filipina) memiliki hari kerja yang sama. Jika ada negara yang memiliki hari libur pada saat di negara lain merupakan hari kerja maka di negara yang terdapat hari libur tersebut akan diperhitungkan tetap sebagai hari kerja dengan menggunakan nilai indeks bulan sebelumnya.

a. Menghitung Return Bulanan

b. Melakukan Uji Stasioner

Pengujian stasioner data yang akan dianalisis dilakukan dengan menggunakan Augmented Dickey-Fuller. Augmented Dickey-Fuller diperlukan agar data menjadi stasioner mengingat dalam penelitian ini data yang digunakan adalah data yang sifatnya time series. Suatu data time series dapat cenderung nonstasioner disebabkan karena trend waktu pengamatannya linier atau eksponensial. Stasioneritas merupakan salah satu pra-syarat penting dalam model ekonometrika untuk data runtun waktu (time series) (Dickey \& Fuller, 1981). Augmented dickey fuller memiliki persamaan:

$\Delta Y_{t}=\vartheta Y_{t-1}+\alpha_{i} \sum_{i=1}^{m} \Delta Y_{t-1}+\varepsilon_{t}$

dimana: $Y_{t}=$ variabel yang diteliti; $\vartheta=$ koefisien regresi; $\mathrm{t}=$ periode; $\mathrm{m}=$ panjang lag; dan $\varepsilon_{t}=$ error term Dengan menggunakan tabel yang sesuai dengan salah satu model time series, maka hipotesis yang akan di uji:

$\mathrm{H} 0: \delta=0$, model tersebut tidak stasioner

Ha : $\delta \neq 0$, model tersebut stasioner

Jika kita tidak menolak hipotesis $\delta=0$, maka $\rho=1$. Artinya kita memiliki unit root, dimana data time series $\mathrm{Y}_{\mathrm{t}}$ tidak stasioner. Null hypothesis yang menyatakan tidak adanya sifat stasioner dalam model akan ditolak, apabila nilai t-statistik yang diperoleh berkaitan dengan koefisien regresi model ini lebih kecil dari nilai t-tabel pada tingkat signifikan tertentu. Apabila nilai probabilitas yang dihasilkan lebih kecil dari $\alpha=5 \%$, maka terjadi penolakan $\mathrm{H} 0$ atau Ha diterima yang berarti data bersifat stasioner. Sebaliknya, bila nilai probabilitas lebih besar dari $\alpha=5 \%$, maka terjadi penerimaan $\mathrm{H} 0$ yang mengindikasikan bahwa data bersifat non-stationer, maka akan dilakukan differencing 1 kali.

c. Metode Vector Auto Regression (VAR)

Pendekatan VAR merupakan rangkaian model time series multivariat yang dikembangkan Sims (1980). VAR adalah suatu sistem persamaan yang memperlihatkan setiap peubah sebagai fungsi linier dari konstanta dan nilai lag dari peubah-peubah yang ada dalam sistem (Enders, 2004). Dalam model VAR, semua variabel yang digunakan dalam analisis dianggap berpotensi menjadi variabel endogen, dengan 
mengabaikan pemisahan antara variabel eksogen dan endogen atau dalam arti lain yaitu semua variabel berhak menjadi variabel dependent dan independent. Selain VAR, terdapat pula VAR FD (Vector Auto Regression First Difference). Perbedaan keduanya terletak pada kestasioneritasan data yang digunakan. Model umum VAR sebagai berikut (Achsani et al, 2005):

$X_{t}=\mu_{t}+i+X_{t-1}+\varepsilon_{t}$

dimana: $X_{t}=$ vektor dari variabel endogen dengan dimensi ( $\left.\mathrm{n} \times 1\right) ; \mu_{t}=$ vektor dari variabel eksogen, termasuk konstanta (intersep) dan tren; $A i=$ koefisien matriks dimensi ( $\mathrm{n} \mathrm{x} \mathrm{n)}$; dan $\varepsilon_{t}=$ vektor dari residual.

- Uji Kestabilan model VAR

Uji ini akan dilakukan dengan metode trial and error dimana lag yang akan dipilih melalui serangkaian percobaan sampai pada lag maksimum yang tidak bisa diterima lagi oleh model/ yang membuat model tidak stabil. Melalui VAR stability condition check, dengan menghitung akar-akar fungsi polinominal atau roots of characteristic polinominal. Jika semua akar dari fungsi polinominal tersebut berada di dalam unit circle atau jika nilai absolutnya $<1$ maka model VAR tersebut dianggap stabil

- Uji Lag Optimum

Uji lag optimum dilakukan untuk memperoleh lag yang tepat untuk digunakan pada uji kausalitas granger. Uji ini dilakukan untuk menenentukan panjang lag yang optimal yang digunakan dalam model. Penentuan jumlah lag optimal yang akan digunakan dalam model granger dapat ditentukan berdasarkan kriteria Akaike Information Criterion (AIC), Schwarz Information Criterion (SC) dan Hannan Quinnon Criterion (HQ). Penentuan panjang lag yang optimal didapat dari persamaan VAR dengan nilai AIC, SC atau HQ yang terkecil (dalam Bapepam, 2008). Rumus untuk menghitung nilai AIC, SC dan HQ adalah:

$\mathrm{AIC}=-2(\mathrm{l} / \mathrm{T})+2(\kappa / \mathrm{T})$

$\mathrm{SC}=-2(\mathrm{l} / \mathrm{T})+\kappa \log (\mathrm{T}) / \mathrm{T}$

$\mathrm{HQ}=-2(\mathrm{l} / \mathrm{T})+2 \kappa \log (\log (\mathrm{T})) / \mathrm{T}$

d. Melakukan Uji Pairwise Granger Causality/Block Exogeneity Wald Tests

Tujuan uji kausalitas granger adalah untuk meneliti apakah X mendahului (menyebabkan) Y ataukah Y mendahului $X$, ataukah hubungan antara $X$ dengan $Y$ saling timbal balik (dua arah), ataukah antara X dan Y tidak ada hubungan sama sekali. Sedangkan persamaan yang digunakan untuk melakukan pengujian Granger Causality, dapat dituliskan sebagai berikut:

$Y_{t}=\sum_{i=1}^{m} a_{i} X_{t-1}+\sum_{j=1}^{n} b_{j} Y_{t-1}+v_{t} ; \mathrm{X} \rightarrow \mathrm{Y}$

$X_{t}=\sum_{i=1}^{r} c_{i} X_{t-1}+\sum_{j=1}^{s} d_{j} Y_{t-1}+\mu_{t} ; \mathrm{X} \rightarrow \mathrm{Y}$

Hasil regresi persamaan tersebut, maka akan dihasilkan empat kemungkinan nilai koefisien regresi, masing-masing nilai koefisien adalah:

1. Jika secara statistik $\sum_{i=1}^{m} a_{i} \neq 0$ dan $\sum_{j=1}^{n} b_{j}=0$, maka terdapat kausalitas satu arah (unidirectional causality) dari (x) ke (y);

2. Jika secara statistik $\sum_{i=1}^{r} c_{i}=0$ dan $\sum_{j=1}^{s} d_{j} \neq 0$, maka terdapat kausalitas satu arah (unidirectional causality) dari (y) ke (x);

3. Jika secara statistik $\sum_{i=1}^{m} a_{i}=0$ dan $\sum_{j=1}^{n} b_{j}=0$, maka antara (y) ke (x) tidak saling mempengaruhi (independence) atau tidak signifikan) antara satu dengan yang lainnya;

4. Jika secara statistik $\sum_{i=1}^{m} a_{i} \neq 0$ dan $\sum_{j=1}^{n} b_{j} \neq 0$, maka antara (y) ke (x) terdapat hubungan kausalitas (feedback atau bilateral causality) antara satu dengan yang lainnya.

Uji kausalitas dilakukan karena ada empat kemungkinan arah kausalitas. Pertama, X menyebabkan $\mathrm{Y}$ apabila hipotesa nol menyatakan $\mathrm{bj}=0$ dengan $\mathrm{j}=1, \ldots, \mathrm{k}$ dapat ditolak $(\mathrm{bj}=0, \mathrm{i}=1,2, \ldots \mathrm{k})$. Kedua, $\mathrm{Y}$ menyebabkan $\mathrm{X}$ apabila hipotesa nol yang menyatakan $\mathrm{bj}=0$ dengan $\mathrm{j}=1, \ldots, \mathrm{k}$ dapat ditolak. Ketiga, hubungan timbal balik terjadi apabila $\mathrm{X}$ menyebabkan $\mathrm{Y}$ dan pada saat yang sama $\mathrm{Y}$ menyebabkan $\mathrm{X}$. Keempat, kedua variabel tersebut saling independen (Kuncoro, n.d). Pengujian dengan uji kausalitas Granger dilakukan dengan melihat nilai probabilitas yang dihasilkan dengan tingkat kepercayaan pada level 5\%. Bila nilai probabilitas lebih kecil dari $\alpha$, maka tolak H0 dan terima Ha. 


\section{HASIL}

ASEAN-5 merupakan kumpulan negara-negara Asia Pasifik yang memiliki letak geografis yang berdekatan, dan didukung pula oleh hubungan kerjasama ekonomi yang kuat. ASEAN-5 yang terdiri dari negara Indonesia, Malaysia, Singapura, Thailand, dan Fhilipina yang merupakan negara pelopor berdirinya ASEAN. ASEAN (Association of Southeast Asian Nations) bertujuan meningkatkan pertumbuhan ekonomi, kemajuan sosial, dan pengembangan kebudayaan negara-negara di Asia Tenggara. Adanya kerjasama ekonomi yang dilakukan sejak didirikannya ASEAN membuat ekonomi negara-negara ASEAN memiliki integrasi. Integrasi yang terjadi bukan hanya terjadi antar negara kawasan ASEAN tapi juga dipengaruhi oleh negara-negara berkembang seperti Amerika Serikat. Integrasi yang terjadi menimbulkan contagion effect seperti yang terlihat melalui perbandingan antar return saham seperti pada Gambar 1 yang menjelaskan bahwa ketika terjadi krisis di Amerika Serikat di akhir tahun 2008 berpengaruh terhadap return saham ASEAN-5. Menurunnya return indeks ASEAN-5 disaat terjadinya krisis Amerika Serikat membuktikan bahwa indeks Amerika memiliki integrasi terhadap ASEAN-5.

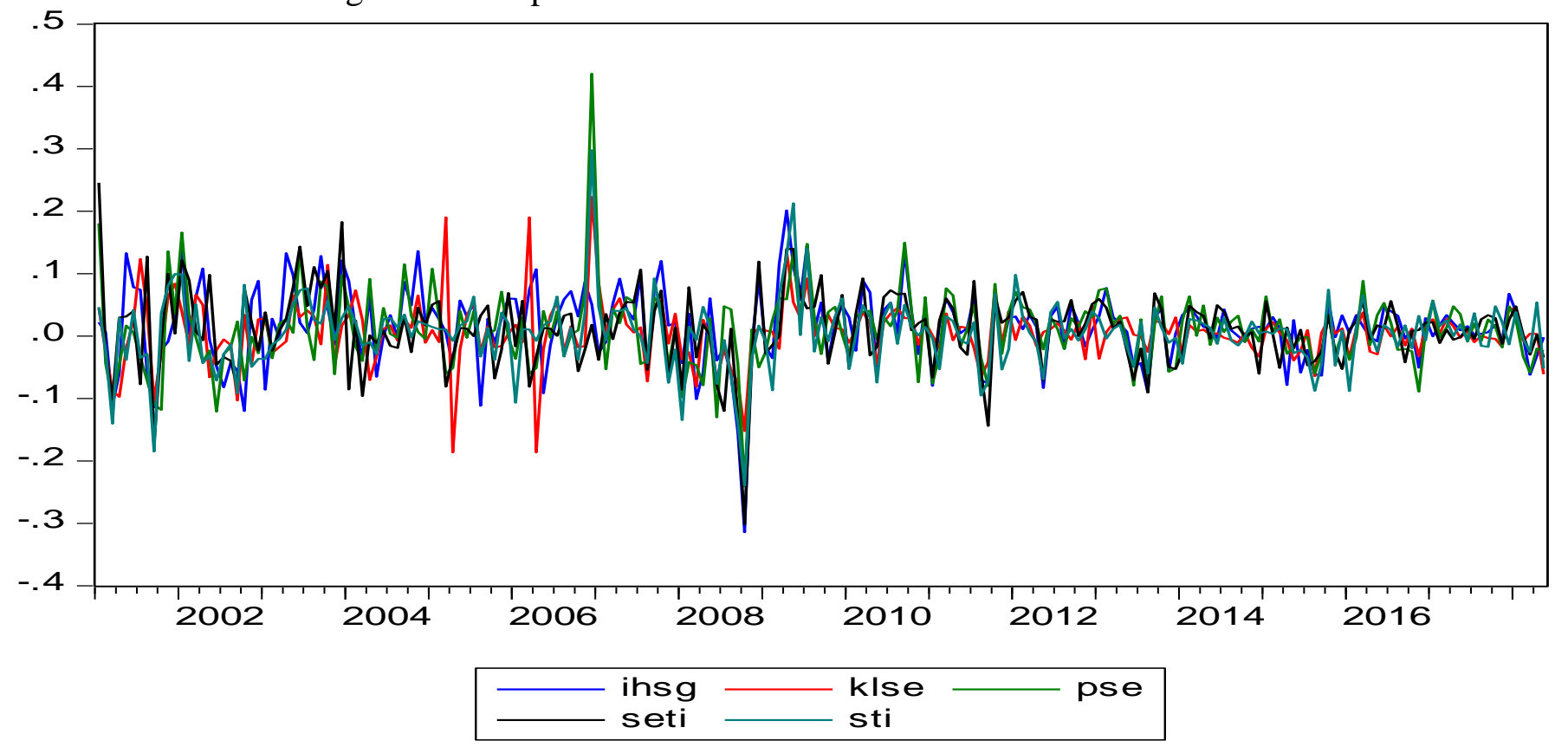

Gambar 1.

Pergerakan Return Saham ASEAN-5 Selama Periode Januari 2001 - Mei 2018

\section{Unit Stationeritas}

Hasil pengujian stasioneritas data return indeks saham ASEAN-5 adalah sebagai berikut:

Tabel 1

Hasil Uji Akar Unit Augmented Dickey-Fuller (ADF) pada tingkat level 0

\begin{tabular}{lllll}
\hline \multirow{2}{*}{ Variabel } & \multirow{2}{*}{ Nilai $_{\text {statistik }} \mathrm{ADF}$} & \multicolumn{4}{l}{ Nilai tristis $_{\text {tabel }}$ McKinnon } & \\
\hline IHSG & -11.30906 & $1 \%$ & $5 \%$ & -2.574161 \\
STI & -12.23587 & -3.461783 & -2.875262 & -2.574161 \\
KLSE & -14.66680 & -3.461783 & -2.875262 & -2.574161 \\
SETI & -13.76347 & -3.461783 & -2.875262 & -2.574161 \\
PSE & -12.75390 & -3.461783 & -2.875262 & -2.574161 \\
\hline
\end{tabular}

Sumber : data olahan

Hasil uji stationeritas dengan uji Augmented Dickey-Fuller (ADF) menunjukkan bahwa semua data return indeks pasar ASEAN-5 yang digunakan stationer pada level 0 , dimana nilai level 0 merupakan nilai nominal dari variabel tersebut (Sudarjah dan Yusuf, 2008). Hasil pengujian ADF test pada Tabel 1 membuktikan bahwa kelima variabel utama yang digunakan dalam model, yaitu IHSG, STI, KLSE, SETI, dan 
PSEI stasioner pada level 0 yang dilihat dari t-statistik ADF lebih besar dari nilai t-kritis Mackinnon untuk semua tingkat keyakinan.

\section{Uji VAR (Vector Autoregression)}

Dalam suatu permodelan, bila tidak diketahui apakah suatu variabel eksogen atau endogen, maka untuk pembentukan model yang melibatkan banyak variabel sebaiknya memperlakukan semua variabel menjadi variabel endogen (Sim, 1980).

a. Uji Kestabilan Model VAR

Setelah dilakukan uji kestabilan model VAR diketahui bahwa model VAR yang digunakan memiliki lag maksimum yaitu pada lag 33. Setelah memasuki lag ke-34, model menjadi tidak stabil dan adanya kecenderungan menjadi model yang tidak stationer. Gambar 2 dapat terlihat bahwa model VAR dengan menggunakan lag maksimal yaitu 33 adalah stabil, karena roots yang ada memiliki modulus $<1$ dan semuanya terletak dalam unit circle.

\section{Inverse Roots of AR Characteristic Polynomial}

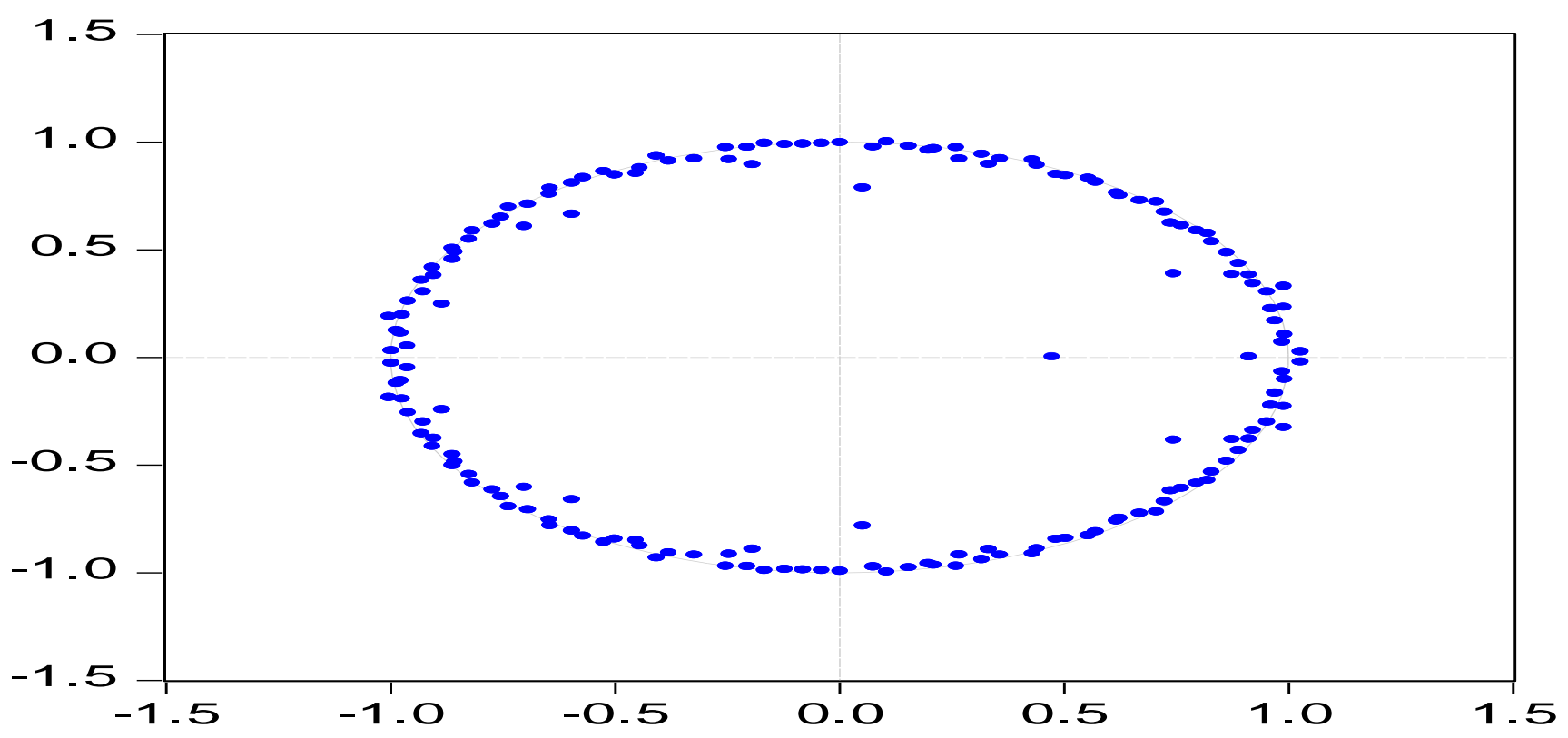

Gambar 2

b. Penentuan Panjang Lag

Hasil Uji Stabilitas VAR (lag 33)

Setelah diketahui panjang lag maksimum akan ditentukan panjang lag yang tepat sesuai dengan menggunakan VAR lag order selection criteria menggunakan AIC, SC, dan HQ. Berdasarkan Tabel 2 diputuskan untuk mengambil lag berdasarkan Schwarz Information Criterion (SIC) yaitu sebesar 0. Penggunaan SIC biasanya dilakukan untuk memilih order model yang lebih rendah dibandingkan jika menggunakan AIC, maka ordo pertama dipilih untuk menghindari over-parameterization (Setyasmoro, 2009).

Tabel 2

Hasil VAR Lag Order Selection Criteria

\begin{tabular}{lll}
\hline Criteria & lag & value \\
\hline AIC (Akaike Information Criterion) & 33 & -27.25478 \\
SIC (Schwarz Information Criterion) & 0 & -17.05484 \\
HQC (Hannan Quinnon Criterion) & 33 & -21.19044 \\
\hline
\end{tabular}

Sumber: data olahan 


\section{Uji Pairwise Granger Causality}

Langkah selanjutnya yang dilakukan adalah melakukan uji granger causality yang akan menghasilkan 4 (empat) kemungkinan nilai koefisien regresi, masing-masing nilai koefisien adalah:

a. Jika secara statistik $\sum_{i=1}^{m} a_{i} \neq 0$ dan $\sum_{j=1}^{n} b_{j}=0$, maka terdapat kausalitas satu arah (unidirectional causality) dari (x) ke (y)

b. Jika secara statistik $\sum_{i=1}^{t} c_{i}=0$ dan $\sum_{j=1}^{s} d_{j} \neq 0$, maka terdapat kausalitas satu arah (unidirectional causality) dari (y) ke (x)

c. Jika secara statistik $\sum_{i=1}^{m} a_{i}=0$ dan $\sum_{j=1}^{n} b_{j}=0$, maka antara (y) ke (x) tidak saling mempengaruhi (independence atau tidak signifikan) antara satu dengan lainnya.

d. Jika secara statistik $\sum_{i=1}^{m} a_{i} \neq 0$ dan $\sum_{j=1}^{n} b_{j} \neq 0$, maka antara (y) ke (x) terdapat hubungan kausalitas (feedback atau bilateral causality) antara satu dengan lainnya.

Hasil uji granger causality berdasarkan VAR pada Tabel 2 dapat dijelaskan bahwa tingkat return IHSG Indonesia sebagai variable dependent tidak dipengaruhi (non-granger cause) oleh tingkat return indeks STI Singapura dengan nilai probability sebesar 0,60996. Sebaliknya tingkat return indeks STI Singapura sebagai variable dependent dipengaruhi (granger cause) tingkat return IHSG Indonesia dengan nilai probability sebesar 0.01448. Jadi dapat dikatakan bahwa tidak terdapat hubungan timbal balik (kausalitas) antara tingkat return IHSG Indonesia dengan return indeks STI Singapura dengan tingkat keyakinan $95 \%$.

IHSG Indonesia sebagai variable dependent tidak dipengaruhi (non-granger cause) return indeks KLSE Malaysia dengan nilai probability sebesar 0.25118. Sebaliknya return indeks KLSE Malaysia sebagai variable dependent dipengaruhi (granger cause) return IHSG Indonesia dengan nilai probability sebesar 0.00159. Jadi dapat dikatakan bahwa tidak terdapat hubungan timbal balik (kausalitas) antara return IHSG Indonesia dengan return indeks KLSE Malaysia dengan tingkat keyakinan 95\%.

Tabel 3

Hasil Uji VAR Granger Causality

\begin{tabular}{lll}
\hline Dependent Variable & Exclude & Probability \\
\hline IHSG & STI & 0.60996 \\
& KLSE & 0.25118 \\
& SETI & 0.01541 \\
STI & PSE & 0.68922 \\
& IHSG & 0.01448 \\
& KLSE & 0.36902 \\
SETI & 0.00434 \\
KLSE & PSE & 0.81826 \\
& IHSG & 0.00159 \\
& STI & 0.04141 \\
SETI & SETI & 0.10702 \\
& PSE & 0.11953 \\
& IHSG & 0.04741 \\
PSE & STI & 0.39459 \\
& KLSE & 0.36112 \\
& PSE & 0.42340 \\
& IHSG & 0.00534 \\
& STI & 0.03301 \\
KLSE & 0.04887 \\
\hline
\end{tabular}

Sumber: data olahan

IHSG Indonesia sebagai variable dependent dipengaruhi (granger cause) return indeks SETI Thailand dengan nilai probability sebesar 0.01541. Sebaliknya return indeks SETI Thailand sebagai variable dependent juga dipengaruhi (granger cause) return IHSG Indonesia dengan nilai probability sebesar 0.04741. Jadi dapat dikatakan bahwa terdapat hubungan timbal balik (kausalitas) antara return IHSG Indonesia dengan return indeks SETI Thailand dengan tingkat keyakinan 95\%. IHSG Indonesia sebagai variable dependent tidak 
dipengaruhi (non-granger cause) return indeks PSE Fhilipina dengan nilai probability sebesar 0.68922. Sebaliknya return indeks PSE Fhilipina sebagai variable dependent dipengaruhi (granger cause) return IHSG Indonesia dengan nilai probability sebesar 0.00534. Jadi dapat dikatakan bahwa tidak terdapat hubungan timbal balik (kausalitas) antara return IHSG Indonesia dengan return indeks PSE Fhilipina dengan tingkat keyakinan 95\%. Indeks STI Singapura sebagai variable dependent tidak dipengaruhi (non-granger cause) return indeks KLSE Malaysia dengan nilai probability sebesar 0.36902. Sebaliknya return indeks KLSE Malaysia sebagai variable dependent dipengaruhi (granger cause) return indeks STI Singapura dengan nilai probability sebesar 0.04141. Jadi dapat dikatakan bahwa tidak terdapat hubungan timbal balik (kausalitas) antara return indeks STI Singapura dengan return indeks KLSE Malaysia dengan tingkat keyakinan $95 \%$. Indeks STI Singapura sebagai variable dependent dipengaruhi (granger cause) return indeks SETI Thailand dengan nilai probability sebesar 0.00434. Sebaliknya return indeks SETI Thailand sebagai variable dependent tidak dipengaruhi (non-granger cause) return indeks STI Singapura dengan nilai probability sebesar 0.39459. Jadi dapat dikatakan bahwa tidak terdapat hubungan timbal balik (kausalitas) antara return indeks STI Singapura dengan return indeks SETI Thailand dengan tingkat keyakinan 95\%. Indeks STI Singapura sebagai variable dependent tidak dipengaruhi (non-granger cause) return indeks PSE Fhilipina dengan nilai probability sebesar 0.81826 . Sebaliknya return indeks PSE Fhilipina sebagai variable dependent dipengaruhi (granger cause) return indeks STI Singapura dengan nilai probability sebesar 0.03301. Jadi dapat dikatakan bahwa tidak terdapat hubungan timbal balik (kausalitas) antara return indeks STI Singapura dengan return indeks PSE Fhilipina dengan tingkat keyakinan $95 \%$.

Indeks KLSE Malaysia sebagai variable dependent tidak dipengaruhi (non-granger cause) return indeks SETI Thailand dengan nilai probability sebesar 0.10702. Sebaliknya juga return indeks SETI Thailand sebagai variable dependent tidak dipengaruhi (non-granger cause) return indeks KLSE Malaysia dengan nilai probability sebesar 0.36112 . Jadi dapat dikatakan bahwa tidak terdapat hubungan timbal balik (kausalitas) antara return indeks KLSE Malaysia dengan return indeks SETI Thailand dengan tingkat keyakinan $95 \%$. Indeks KLSE Malaysia sebagai variable dependent tidak dipengaruhi (non-granger cause) return indeks PSE Fhilipina dengan nilai probability sebesar 0.11953. Sebaliknya return indeks PSE Fhilipina sebagai variable dependent dipengaruhi (granger cause) return indeks KLSE Malaysia dengan nilai probability sebesar 0.04887. Jadi dapat dikatakan bahwa tidak terdapat hubungan timbal balik (kausalitas) antara return indeks KLSE Malaysia dengan return indeks PSE Fhilipina dengan tingkat keyakinan 95\%. Indeks SETI Thailand sebagai variable dependent tidak dipengaruhi (non-granger cause) return indeks PSE Fhilipina dengan nilai probability sebesar 0.42340 . Sebaliknya return indeks PSE Fhilipina sebagai variable dependent dipengaruhi (granger cause) return indeks SETI Thailand dengan nilai probability sebesar 0.00557. Jadi dapat dikatakan bahwa tidak terdapat hubungan timbal balik (kausalitas) antara return indeks PSE Thailand dengan return indeks SETI Thailand dengan tingkat keyakinan $95 \%$. Gambar 3.

Hasil dari uji granger causality pada Tabel 3, maka didapat hubungan 1 (satu) arah yang terlihat pada

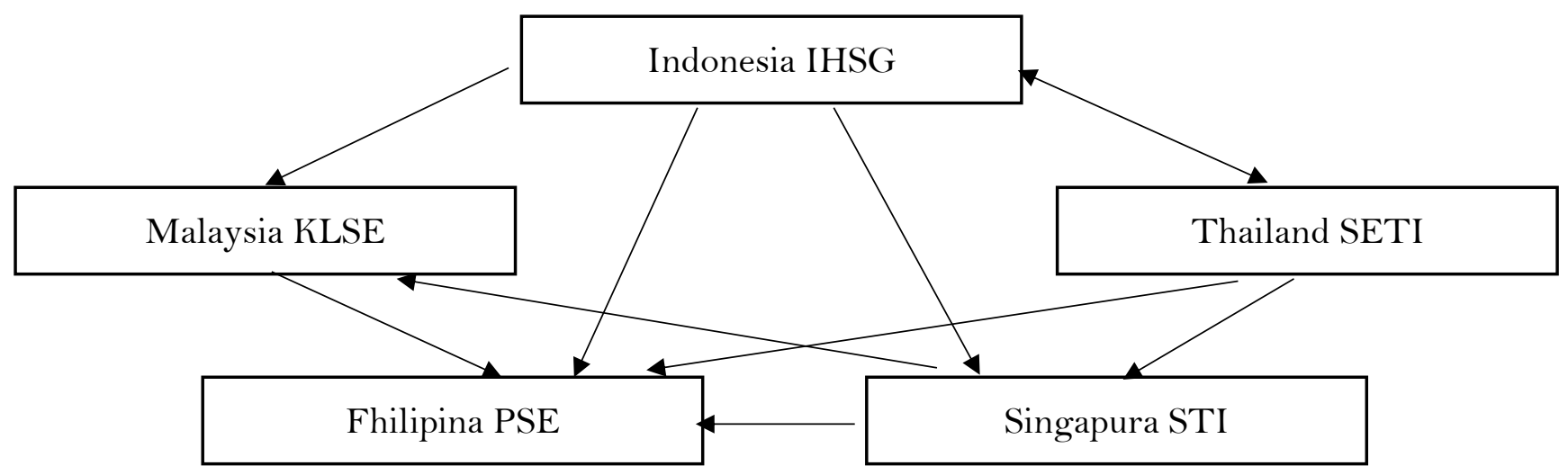

Gambar 3

Hasil Uji Granger Causality

Contagion Effect Antar Negara Asean-5 


\section{Pembahasan}

Riset Eun \& Shim (1989) mengungkapkan pasar Amerika Serikat adalah pasar modal yang paling berpengaruh, sehingga perubahan pasar Amerika Serikat, sehingga perubahan yang Amerika Serikat akan mempengaruhi pergerakan pasar modal lainnya. Hasil penelitian ini mengungkapkan bahwa tidak semua negara ASEAN-5 memiliki hubungan kausalitas (timbal balik), hanya pasar modal Indonesia yang memiliki hubungan kausalitas dengan pasar modal Thailand. Sedangkan negara ASEAN lainnya dalam penelitian ini hanya memiliki satu arah, bahkan pasar modal Thailand tidak terdapat hubungan dengan pasar modal Malaysia yang signifikan, sedangkan pasar modal lainnya hanya terdapat 1 (satu) arah dengan pasar modal 4 negara ASEAN lainnya.

Contagion effect theory menyatakan bahwa terdapat 2 (dua) penyebab utama terjadinya contagion effect; yaitu 1) interpendensi adanya saling ketergantungan antar ekonomi pasar seperti kesamaan makroekonomi, hubungan dagang, dan pinjaman dari bank (Barry, Rose \& Wyploz, 1996); dan 2) prilaku investor, jenis contagion ini berasal dari asimetri information, yaitu perilaku secara kolektif dan hilangnya kepercayaan tanpa memandang kinerja makroekonomi suatu negara yang bersangkutan. Contagion effect selama periode pangamatan 2001.1 - 2018.5 hanya terjadi pada 1 (satu) composite index yang memiliki hubungan 2 arah terhadap pasar modal ASEAN lainnya, yaitu pasar modal Indonesia dengan pasar modal Thailand. Hasil penelitian ini juga membuktikan bahwa pasar modal Indonesia mempengaruhi pergerakan indeks saham ASEAN lainnya dan memperkuat PEKKI (Perkembangan Ekonomi Keuangan dan Kerjasama Internasional) yang diterbitkan Bank Indonesia (BI) mengungkapkan bahwa negara Indonesia merupakan negara pertama diantara kelima negara ASEAN-5 yang berhasil pulih dari kontraksi akibat krisis yang terjadi dan kemudian menopang pertumbuhan ekonomi ASIA pada triwulan kedua tahun 2009. Negara Indonesia merupakan salah satu negara eksportir komoditas yang dibutuhkan hampir semua negara sekalipun terjadi krisis. Kegiatan ekspor yang dimiliki negara Indonesia dari komoditas yang dibutuhkan negara lain tentunya membawa dampak positif bagi cadangan devisa kedua negara tersebut. Cadangan devisa yang meningkat berdampak bagi peningkatan kepercayaan investor baik dari dalam maupun dari luar negari dan tentu saja berdampak positif bagi pasar modal Indonesia.

\section{SIMPULAN}

Berdasarkan hasil penelitian diperoleh kesimpulan sebagai berikut:

a. Tidak semua return indeks negara ASEAN-5 (Indonesia, Singapura, Malaysia, Thailand, dan Filipina) saling mempengaruhi (kausalitas) secara signifikan selama periode 2001.1-2018.5.

b. Return indeks negara saling mempengaruhi secara signifikan hanya terjadi pada 2 (dua) negara dari ASEAN-5, yaitu indeks komposit negara Indonesia (IHSG) dan indeks komposit negara Thailand (SETI) dengan tingkat keyakinan $95 \%$.

\section{DAFTAR PUSTAKA}

Adisetiawan, R., 2017, Globalisasi Pasar Modal Dunia dan Pengaruhnya Terhadap Pasar Modal Indonesia, Ekonomis: Jurnal of Economics and Business, 1(1): 10-17

Adisetiawan, R., 2012, Kausalitas BI Rate, Inflasi, dan Indeks Harga Saham, Manajemen \& Bisnis, 11(2), 256-265

Achsani, N.A., O. Holtemöller and H. Sofyan, 2005. Econometric and Fuzzy Modelling of Indonesian Money Demand. in: Pavel Cizek, Wolfgang H., and Rafal W. Statistical Tools For Finance and Insurance. Berlin Heidelberg, Germany: Springer-Verlag

Amir, Amri., 2007. Pengaruh inflasi dan pertumbuhan ekonomi terhadap pengangguran di Indonesia. Jurnal Inflasi dan Pengangguran, 1(1)

Ang, Robert., 1997. Buku Pintar Pasar Modal Indonesia, Jakarta: Mediasoft Indonesia

Atmadja, Adwin Surja. n.d. The US and The ASEAN-5 Stock Exchanges Linkages In The Periods of Stock Market Turnoil. Retrieved February 1, 2013, from http://repository.petra.ac.id/15426/1/jurnas_perbanas_THE_US_AND_THE_ASEAN5_STOCK_EXC HANGES_LINKAGES_IN_THE_PERIODS_OF_STOCK_MARKET_TURMOIL.pdf 
Badan Pengawas Pasar Modal dan Lembaga Keuangan Departemen Keuangan Republik Indonesia. (2008). Analisis hubungan kointegrasi dan kausalitas serta hubungan dinamis antara aliran modal asing, perubahan nilai tukar dan pergerakan IHSG di Pasar Modal Indonesia. Retrieved December 31, 2011, from

http://www.bapepam.go.id/pasar_modal/publikasi_pm/kajian_pm/studi2008/Aliran_Dana_Asing.pdf

Barry, E., Rose, A. \& Wyplosz, C. 1996. Contagious Currency Crises. CEPR Discussion Paper No. 1453. London: Center for Economic Policy Research, August

Charemza, W., Woijciech, \& Deadman, F., Derek. 1992. New Directions in Econometric Practice, England: Edward Elgar

Darmadji, T., \& Fakhruddin, H. M. 2011. Pasar Modal di Indonesia : Pendekatan Tanya Jawab. Jakarta ., T dan Hendy., M.F. 2001, Pasar Modal di Indonesia Pendekatan Tanya Jawab, Edisi Pertama,Jakarta : Salemba Empat

Darmawan, Fajar.B. 2009. Pengaruh Indeks DJI, FTSE 100, NKY 225, dan HIS terhadap Indeks Harga Saham Gabungan Sebelum, Ketika, dan Sesudah Subprime Mortgage Pada Tahun 2006-2009. (No. 20939/PS/MM/06). Published thesis, Universitas Gajah Mada, Yogyakarta

Dickey, David A. \& Fuller, Wayne A. 1981. Likelihood Ratio Statistics for Autoregressive Time Series with a Unit Root, Econometrica, 49(4), Retrieved July 2, 2013, from http://www.u.arizona.edu/ rlo/readings/278800.pdf

Dornbusch, R. \& Fischer, S.. 1980, Exchange Rates and Current Account, American Economic Review, 70, 960-971

Dwiyanti, Venny. 2012. Analisa Comovement Indeks Harga Saham Pada Negara China, India, Indonesia, Malaysia, Singapura, Hong Kong dan Korea Selatan Periode Pengamatan 2000-2010. (TA No. 37010149/MAN/2012). Unpublished undergraduate thesis, Universitas Kristen Petra, Surabaya.

Enders, Walter., 2004. Applied Econometric Times Series, International Edition, Wiley \& Sons, Incorporated, John

Etzel, B.J. 2003. Finance and Investment Dictionary. Indianopolis, Indiana: Wiley Publishing, Inc.

Eun, Cheol S. dan Sangdal Shim, 1989, International Transmission of Stock Market Movement, Journal of Financial Quantitative Analysis, June, pp. 241-255.

Gujarati, D N., \& Zain, Sumarno. 1988. Ekonometrika Dasar. Jakarta: Erlangga , D N., 2006. Essential of Econometrics ( $3^{\text {rd }}$ ed). New York: Mc. Graw Hill.

Gunawan, Luhur. (2012). Dampak Krisis Eropa di Indonesia. Retrieved March 4, 2013, from http://infografis.kompas.com/read/2012/06/15/230651/Dampak.Krisis.Ero\%20pa.di.Indonesia

Gustia, Irna. 2008. IHSG Terguling 92 Poin ke 1.244. Retrieved March 4, 2013, from http://finance.detik.com/bursa-valas/1025532/ihsg-terguling-92-poin-ke-1244

Harjito, D. A. 2010, Perubahan Musiman (seasonality) Pasar Modal dan Efek Kontagion di Negara-Negara ASEAN, Jurnal Siasat Bisnis (14):1-18. Retrieved November 29, 2012, from http://journal.uii.ac.id/index.php/JSB/article/view/2025/1779

Harris, Richard., \& Sollis, Robert. 2003. Applied Time Series Modelling And Forecasting, England: Wiley. Hendrawan, Riko. 2011. Kointegrasi Bursa-Bursa Saham di ASIA, Jurnal Keuangan dan Perbankan (15), 159-167. Retrieved September 27, 2012, from http://jurkubank.files.wordpress.com/2012/01/01ricohendrawan_encr ypted.pdf

Horen, Neeltje Van., Jager, Henk \& Klassen Frac. 2006. Foreign Exchange Market Contagion in The Asian Crisis: A Regression-Based Approach, Review of World Economic's, 142: 374-401 Retrieved March 4, 2013, from http://www1.fee.uva.nl/pp/klaassen/index_files/WApublication.pdf

Husnan, Suad. 2003. Dasar-dasar teori portofolio dan analisis sekuritas. Edisi ketiga. Yogyakarta.

Kasiram, Mohammad. 2008. Metodologi Penelitian Kualitatif-Kuantitaif, Malang: UIN Malang Press

Kementerian Perindustrian Republik Indonesia, 30 Negara Asal Ekspor Terbesar Untuk Produk Hasil Industri, Retrieved May 15, 2013, from http://www.kemenperin.go.id/statistik/negara.php

Kim, S. J. \& Sheen, J. 2001. International Linkages and Macroeconomic News Effects on Interest rate Volatility - Australia and The US. Pacific-Basin Finance Journal, 8: 85-113

Kolb, W., Robert, 2011. Financial Contagion the Viral Threat to the Wealth of Nations, New Jersey: Wiley. 
Krisis Global 2008. 2009. Retrieved April 29, 2013, from http://www.indonesiarecovery.com/krisiskeuangan-global-2008/krisis-2008-terparah-sejak-the-great-depression/7-krisis-global-2008.html

Krugman, P. 1999. Balance Sheets, the Transfer Problem, and Financial Crises, International Tax and Public Finance, Springer, 6(4):459-472

Lee, Yi., Hsien., 2012, Contagion in International Stock Markets during the Sub Prime Mortgage Crisis, International Journal of Economics and Financial Issues, 2:41-53. Retrieved September 16, 2013, from http://www.econjournals.com//

Nasarudin M. I., Surya I., 2004. Aspek Hukum Pasar Modal Indonesia. Jakarta: Kencana.

Nasution, Amran. 2008. Memahami Krisis Ekonomi Amerika \& Akar Penyebabnya. Retrieved February 28, 2013, from http://www.pkspiyungan.org/2008/10/memahami-krisis-ekonomi-amerika-akar.html

Nesty, Mita. 2013. Pengaruh Krisis Ekonomi Amerikat Serikat Terhadap Bursa Saham dan Perdagangan Indonesia. 90-104. Retrieved April 29, 2013, from http://www.bi.go.id/NR/rdonlyres/2B8CDD271FD7-4D15-9B70-24A0AB949130/28616/MitaNezky.pdf

Otoritas Jasa Keuangan, 2016. Panduan Investasi di Pasar Modal Indonesia, Retrieved 30 March, 2016, from http://www.ojk.go.id/old/old/news/Juni2016/BAB\%20I.pdf

Prasetyantoko, A. 2008. Bencana Finansial Stabilitas Sebagai Barang Publik, Jakarta: Kompas

Pratiwi, Monica Weni. 2012. Pendekatan Contagion Theory Terhadap Krisis Dubai, Media Riset Akuntansi, 2(1): 82-98. $\quad$ Retrieved March 4, 2013, from http://journal.bakrie.ac.id/index.php/journal_MRA/article/view/49

Qomariyah, Nurul. 2009. Kronologi dan Latar Belakang Krisis Finansial Global. Retrieved April 29, 2013, from http://finance.detik.com/read/2009/04/15/120601/1115753/5/kronologi-dan-latar-belakang-krisisfinansial-global

Rachman, Taufik. 2012. Menkeu Optimis Ri Mampu Hadapi Krisis Eropa. Retrieved Februari 28, 2013, from http://www.republika.co.id/berita/ekonomi/keuangan/12/05/26/m4mgig-menkeu-optimistis-ri-mampuhadapi-krisis-eropa

Rijckeghem Bureau of Export Trade Promotion (BETP), Philippine Merchandise Total Trade, 2007-2010, Retrieved May 15, 2013, from http://www.dti.gov.ph/uploads/DownloadableForms

Rijckeghem, V. C. \& Weder, B. (1999), Sources of Contagion : Finance or Trade?. IMF Working Papers 99/146. International Monetary Fund

Salamah, Lilik. 2010. Jurnal Masyarakat Kebudayaan dan Politik. Retrieved February 28, 2013, from http://mkp.fisip.unair.ac.id

Sanjoko, Andy. 2013. Analisa Monthly Effect dan Pengaruh Krisis Tahun 1997-1998 Terhadap Monthly Effect di Indonesia. (TA No. 37010184/MAN/2013). Unpublished undergraduate thesis, Universitas Kristen Petra, Surabaya.

Setyasmoro, Rahardian, 2009. Analisis Cointegration dan Error Correction Model Indeks Bursa Global dan Regional Asia Terhadap Indeks Harga Saham Gabungan (Studi Empiris: 2004-2008). Retrieved December 5, 2011, from http://www.lontar.ui.ac.id/file?file=digital/130519-T\%2027251Analisis\%20cointegration-Metodologi.pdf

Siamat, Dahlan. 2005. Manajemen Lembaga Keuangan; kebijakan moneter dan perbankan (Edisi kelima), Jakarta: Lembaga Penerbit Fakultas Ekonomi Universitas Indonesia.

Sims, C. A., 1980, Macroeconomics and reality, Econometrica, 48(1):1-48

Sims, C. A., and Zha, T. 1998. Bayesian Methods for Dynamic Multivariate Models, International Economic Review, 39(4): 949-968

Sumantoro. 1988. Aspek-Aspek Hukum Dan Potensi Pasar Modal Di Indonesia, Jakarta: Ghalia Indonesia

Supranto, J,. 2004. Statistik Pasar Modal Keuangan dan Perbankan, Edisi Revisi, Penerbit Rineka Cipta, Jakarta

Tandelilin, Eduardus. 2001. Analisis Investasi dan Manajemen Portofolio, Edisi Pertama. Yogyakarta: BPFE Tan, Jose Antonio R, 1998, Contagion Effects During the Asian Financial Crisis: Some Evidence from Stock Price Data (Pacific Basin Working Paper Series. Center for Pacific Basin Monetary and Economic Studies Economic Research Department Federal Reserve Bank of San Francisco. Thailand., Stock 
Exchange. Total Return Index. Retrieved $\quad$ February 25 2013, from http://www.set.or.th/en/market/tri.html

The Department of The Treasury. 2012. Recent U.S. Economic Growth In Charts. Washington, DC: Author. Retrieved April 29, 2013, from http://www.treasury.gov/resource-center/datachartcenter/Documents/20120502_EconomicGrowth.pdf

The World Bank. GDP, Economic Growth, inflation and money supply, export import, net foreign assets. (2005-2011). Retrieved March 5, 2013, from http://data.worldbank.org/

Trihadmini, Nuning. 2011, Contagion dan Spillover Effect Pasar Keuangan Global Sebagai Early Warning System. $\quad$ Retrieved March 30, 2013, from http://perbanasinstitute.ac.id/jurnal/artikel/vol13_no1_juni2011_art_04.PDF

Wondabio, L.S., 2006. Analisa Hubungan Index Saham Gabungan (IHSG) Jakarta (JSX), London (FTSE), Tokyo (NIKKEI), dan Singapura (SSI), Simposium Nasional Akuntansi. Retrieved March 4, 2013, from http://blog.umy.ac.id/ervin/files/2012/06/K-AKPM-07.pdf

Yang, Tracy. 2002, Crisis, Contagion, and East Asian Stock Markets, Institute of Southeast Asian studies.

Yoshendy, Andy. 2012, Kajian Dampak Krisis Keuangan Subprime Terhadap Perekonomian Indonesia, Program Magister Manajemen dan Bisnis Institut Pertanian Bogor 